\title{
The Study on Financial Risk Identification based on Matrix Model
}

\author{
Haoyang Xu \\ School of Economics \\ Wuhan University of Technology \\ Wuhan, China \\ E-mail: 651223896@qq.com
}

\begin{abstract}
In this paper, the author thinks that financial risk identification is core and basis of enterprise risk management and that enterprise's financial risk is correlated with competitiveness. It puts forward threedimensional financial risks identifying principles including index system and matrix model to support enterprise's risk management and competitiveness theory. It explores the identification principle of three-dimensional financial risks so as to give an efficient method. It explains the principle and builds matrix models to identify financial risks from three dimensions.
\end{abstract}

Keywords- Financial risk; matrix model; risk management

\section{INTRODUCTION}

In modern risk management theories, enterprise is always taken as "organism" constituted by multidimensional risks and values which is the premise and foundation for enterprise to take part in market competition. So, risk, value and competitiveness are the basic survival characteristics of enterprise. However, for the reason of increasingly fierce and dynamic competitiveness, enterprise is always face financial risks to convert values and create competitive advantages so as to enhance competitiveness and realize sustainable development under the guidance of strategies [5]. Michael Porter's diamond model theory (1990) [4] points out that four factors can determine competitiveness what are factor conditions, demand conditions, related and supporting industries, firm strategy, structure and rivalry. Argenti (1976) thought that enterprise's survival factors can be divided into three types including the characteristic of enterprise itself, the characteristic of industry and the characteristic of environment [1]. So, uncertainty is an important characteristic and risk management is the essential content of enterprise..

\section{POWERLINE COMMUNICATION}

From the current literatures, we can see that financial risks are often classified as investment risk (INR), financing risk (FIR) and other major categories. And these classification methods are always emphasis on the capital operational status. So many hypothesizes must be used to judge the validity of capital market, such as no-arbitrage equilibrium hypothesis, assumption of diminishing marginal utility of capital, risk aversion hypothesis, asymmetric information hypothesis and so on. S. Peng and J. Xing, according to the cycle of capital movements, divided financial risks into capital allocation risk (CAR), capital consumption risk (CCR), capital output risk (COR), capital recovery risk (CRR), capital payment risk (CPR) and capital market risk (CMR) (2005) [3].

Understanding and grasping formation and conduction mechanism of financial risks from three dimensions are the premise and basis of financial risks identification. As an independently operating "organism", enterprise must get conditions to ensure its sustainable operation, including sustainable value-flow inputting, effective value transformation and sustainable value-flow outputting. And this is a cycling and amplifying process. Sustainable valueflow inputting reflects interactive adaptation between enterprise and external environment, and value transformation manifests enterprise's ability for resource allocation, and sustainable value-flow outputting is the expected result of stakeholders to benefits. Limited by the subjective and objective conditions, enterprise's valuechain isn't unchangeable, uncertainty and difference and danger construct the main features of enterprise's value activities. So FEAR, FRAR and FSCR make up three dimensions of enterprise's financial risks, and their formation and conduction mechanism decide enterprises' value characteristics.

OPR generally refers to uncertainty of profit amount or profit rate for the reason of operation. INR is the danger to gain uncertain expected profit, generally means uncertainty of return in enterprise's investment. FIR is the possibility of losing debt paying ability or changeability of profit. FCR is the possibility of enterprise out of control its cashflow and leading to fund chain fracture. Likewise, FSCR is the uncertainty and loss possibility for finance to meet the value expectations of stakeholders. It can be classified as consumer cooperation risk (CCR), other stakeholder cooperation risk (OCR) and long-term profit cooperation risk (LPR). CCR is the possibility of enterprise's financial loss for the reason of consumer relation failure. OCR is the possibility of enterprise's financial loss for the reason of other stakeholder relation failure. LPR is the possibility of enterprise's losing endurable profit and cooperation ability. Types of enterprise's three-dimensional financial risks are shown in TABLE I. 
TABLE I. TYPES OF THREE-DIMENSIONAL FINANCIAL RISKS

\begin{tabular}{|c|c|c|}
\hline Risk Category & Risk Type & In Short \\
\hline \multirow{3}{*}{$\begin{array}{c}\text { Financial } \\
\text { environment- } \\
\text { adaptation risk } \\
\text { (FEAR) }\end{array}$} & Financial environmental risk & FER \\
\hline & Market competition risk & MCR \\
\hline & Element fluctuation risk & EFR \\
\hline \multirow{4}{*}{$\begin{array}{c}\text { Financial } \\
\text { resource- } \\
\text { allocation risk } \\
(\text { FRAR })\end{array}$} & Operational risk & OPR \\
\hline & Investment risk & INR \\
\hline & Financing risk & FIR \\
\hline & Funding chain risk & FCR \\
\hline \multirow{3}{*}{$\begin{array}{c}\text { Financial } \\
\text { stakeholder- } \\
\text { cooperation risk } \\
\text { (FSCR) }\end{array}$} & Consumer cooperation risk & CCR \\
\hline & $\begin{array}{c}\text { Other stakeholder cooperation } \\
\text { risk }\end{array}$ & OCR \\
\hline & $\begin{array}{c}\text { Long-term profit cooperation } \\
\text { risk }\end{array}$ & LPR \\
\hline
\end{tabular}

\section{IDENTIFICATION PRINCIPLES}

To identify three-dimensional financial risks of enterprise, this paper defines risk controlling point as the benchmark and each risk index calculated value $t_{i}$ can be compared with it. If the risk controlling point value is $\eta$, then the compared value can be expressed as $\mathrm{V} t / \eta$, $\mathrm{V} t=\eta-t_{i}$. So, we can judge the risk levels by the value of $\mathrm{V} t / t$. This paper classifies the financial risk level into four types from the development path along with time, which is "none-crisis", "latent crisis", "developing crisis" and "crisis". "none-crisis", which can be shown as green warning light, means that the financial risk is very small and cannot bring about any crisis. "latent-crisis", which can be shown as yellow warning light, means that the financial crisis is in the latent status and can be controlled stably. "developing-crisis", which can be shown as orange warning light, means that the financial risk is in the development period and the financial crisis is rapidly brewing. "crisis", which can be shown as red warning light, means that the financial risk is very large and the financial crisis is appeared. The principle of financial risk identification can be interpreted as Fig. 1.

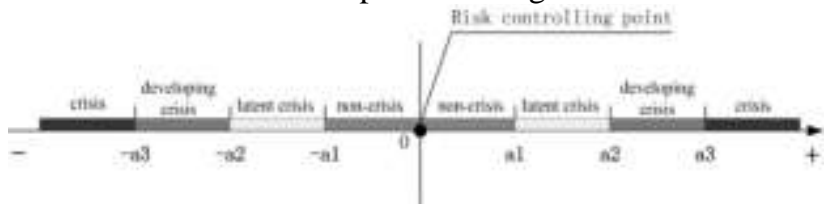

Figure 1. Identification principle of financial risk

If the judgment threshold vector set is defined $A=\left[a_{1}, a_{2}, a_{3}\right]$, the value of risk controlling point is $\eta$, the index value is, we can construct identifying models to identify three-dimensional financial risks. This paper uses $\mathrm{R}$-values to judge the risk levels (see TABLE II). It defines:

- If the calculated value $0 \leq\left|\left(\eta-t_{i}\right) / \eta\right|<a_{1}$ then $R \in[0,1]$. It means financial risk is very small and the financial crisis can not occur, so the risk level is "nonecrisis".
- If the calculated value $a_{1} \leq\left|\left(\eta-t_{i}\right) / \eta\right|<a_{2}$ $R \in[1,2]$

then $R \in[1,2]$. It means financial risk can be controlled stably and financial crisis is in the latent status, so the risk level is "latent crisis".

- If the calculated value $a_{2} \leq\left|\left(\eta-t_{i}\right) / \eta\right|<a_{3}$, $R \in[2,3]$

It means financial risk is high and financial crisis is developing, so the risk level is "developing crisis".

- If the calculated value $a_{3} \leq\left|\left(\eta-t_{i}\right) / \eta\right|$, then $\mathrm{R}=3$. It means financial risk is very high and financial crisis is appeared, so the risk level is "crisis".

The calculation formula of R-value can be expressed as:

$$
R=\left\{\begin{array}{l}
\frac{\left|\left(\eta-t_{1}\right) / \eta\right|}{a_{1}} \quad \text { if } 0 \leq\left|\left(\eta-t_{i}\right) / \eta\right|<a_{1} \\
\frac{\left|\left(\eta-t_{1}\right) / \eta\right|-a_{1}}{a_{2}-a_{1}}+1 \quad \text { if } a_{1} \leq\left|\left(\eta-t_{i}\right) / \eta\right|<a_{2} \\
\frac{\left|\left(\eta-t_{1}\right) / \eta\right|-a_{2}}{a_{3}-a_{2}}+2 \quad \text { if } a_{2} \leq\left|\left(\eta-t_{i}\right) / \eta\right|<a_{3} \\
3 \quad \text { if } a_{3} \leq\left|\left(\eta-t_{i}\right) / \eta\right|
\end{array}\right.
$$

TABLE II. JUDGMENT OF FINANCIAL RISKS

\begin{tabular}{|c|c|c|}
\hline R-value & Risk Level & Means \\
\hline$[0,1)$ & none-crisis & $\begin{array}{c}\text { Financial risk is very small and } \\
\text { financial crisis can not occur. }\end{array}$ \\
\hline$[1,2)$ & latent crisis & $\begin{array}{c}\text { Financial risk can be controlled } \\
\text { stably and financial crisis is in the } \\
\text { latent status. }\end{array}$ \\
\hline$[2,3)$ & $\begin{array}{c}\text { developing } \\
\text { crisis }\end{array}$ & $\begin{array}{c}\text { Financial risk is high and financial } \\
\text { crisis is developing. }\end{array}$ \\
\hline 3 & crisis & $\begin{array}{c}\text { Financial risk is very high and } \\
\text { financial crisis is appeared. }\end{array}$ \\
\hline
\end{tabular}

We can treat an enterprise as a financial risk space system U including some financial risks subsystems Ui, suppose each risk subsystem can satisfy the conditions of boundary and differentiable, therefore the risk controlling point of every subsystem exists. Because the calculation of enterprise's risk controlling point is complicated and difficult, this paper classifies it by industries and adopts the industry's three years' data of feature samples, and the calculation result is approximately treated as the industry risk controlling point. If $\eta_{i}$ is risk controlling point's value of i-th index, ${ }^{k}{ }_{i j}^{k}$ is $\mathrm{i}$-th index value of $\mathrm{j}$-th sample in $\mathrm{k}$-th year. Then, risk controlling points' calculating function can be expressed as:

$$
\eta_{i}=\frac{1}{3 n} \sum_{k=1}^{3} \sum_{j=1}^{n} t_{i j}^{k}
$$




\section{MATRIX MODEL BUILDING}

To build a basic matrix model for three-dimensional financial risks identification, this paper divides twodimensional plane into 16 regions, and uses $\mathrm{A} \sim \mathrm{P}$ to represent the risk identification type of each region (see Figure 2), so a financial risk identification types set can be expressed as:

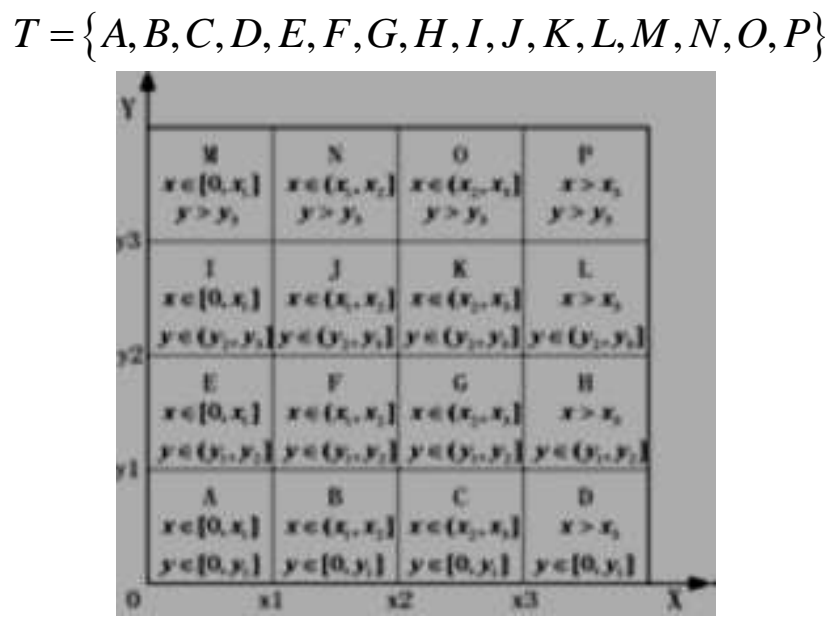

Figure 2. Basic matrix model for financial risk identification

Given the threshold value set of $\mathrm{X}$ is $\{\mathrm{x} 1, \mathrm{x} 2, \mathrm{x} 3\}$ and the threshold value set of $\mathrm{Y}$ is $\{\mathrm{y} 1, \mathrm{y} 2, \mathrm{y} 3\}$, we can judge the financial risk level by $\mathrm{R}$-value of $\mathrm{x}$-axis and $\mathrm{R}$-value of $\mathrm{y}$-axis. For example, if the calculated $\mathrm{R}$-value scope is $\mathrm{Rx}$ $\in(\mathrm{x} 1, \mathrm{x} 2]$ and $\mathrm{Ry} \in(\mathrm{y} 1, \mathrm{y} 2]$, then the financial risk identification type is " $F$ ", which means the financial risk of $\mathrm{x}$-axis is at the second level and the financial risk of $\mathrm{y}$-axis is also at the second level.

For the reason of the accumulation and expansion characteristic of financial risk, we use R-value to measure the risk level, and a different R-value corresponds to a different risk areas. The general interpretation of matrix region is in TABLE III.

TABLE III. MEANINGS OF MATRIX REGION IN THE MODEL

\begin{tabular}{|c|c|c|c|c|c|c|}
\hline Regio & \multicolumn{3}{|c|}{$\mathbf{X}$} & \multicolumn{3}{|c|}{$\mathbf{Y}$} \\
\hline & $\begin{array}{c}\text { Econo } \\
\text { mic } \\
\text { Meanin } \\
\text { gs }\end{array}$ & $\begin{array}{l}\text { Index } \\
\text { Scope }\end{array}$ & $\begin{array}{c}R- \\
\text { value }\end{array}$ & $\begin{array}{c}\text { Econ } \\
\text { omic } \\
\text { Mean } \\
\text { ings } \\
\end{array}$ & $\begin{array}{l}\text { Index } \\
\text { Scope }\end{array}$ & $\begin{array}{c}R- \\
\text { value }\end{array}$ \\
\hline $\mathrm{a}$ & $\begin{array}{l}\text { non- } \\
\text { crisis }\end{array}$ & {$[0, x 1]$} & {$[0,1]$} & $\begin{array}{l}\text { non- } \\
\text { crisis }\end{array}$ & {$[0, \mathrm{y} 1]$} & {$[0,1]$} \\
\hline $\mathrm{b}$ & $\begin{array}{l}\text { latent } \\
\text { crisis }\end{array}$ & {$[\mathrm{x} 1, \mathrm{x} 2]$} & {$[1,2]$} & $\begin{array}{l}\text { non- } \\
\text { crisis }\end{array}$ & {$[0, \mathrm{y} 1]$} & {$[0,1]$} \\
\hline $\mathrm{c}$ & $\begin{array}{c}\text { develo } \\
\text { ping } \\
\text { crisis }\end{array}$ & {$[\mathrm{x} 2, \mathrm{x} 3]$} & {$[2,3]$} & $\begin{array}{l}\text { non- } \\
\text { crisis }\end{array}$ & {$[0, \mathrm{y} 1]$} & {$[0,1]$} \\
\hline $\mathrm{d}$ & crisis & $\geq_{x 3}$ & 3 & $\begin{array}{l}\text { non- } \\
\text { crisis }\end{array}$ & {$[0, \mathrm{y} 1]$} & {$[0,1]$} \\
\hline $\mathrm{e}$ & $\begin{array}{l}\text { non- } \\
\text { crisis }\end{array}$ & {$[0, \mathrm{x} 1]$} & {$[0,1]$} & $\begin{array}{l}\text { latent } \\
\text { crisis }\end{array}$ & {$[\mathrm{y} 1, \mathrm{y} 2]$} & {$[1,2]$} \\
\hline $\mathrm{f}$ & $\begin{array}{l}\text { latent } \\
\text { crisis }\end{array}$ & {$[\mathrm{x} 1, \mathrm{x} 2]$} & {$[1,2]$} & $\begin{array}{l}\text { latent } \\
\text { crisis }\end{array}$ & {$[\mathrm{y} 1, \mathrm{y} 2]$} & {$[1,2]$} \\
\hline g & $\begin{array}{c}\text { develo } \\
\text { ping } \\
\text { crisis }\end{array}$ & {$[\mathrm{x} 2, \mathrm{x} 3]$} & {$[2,3]$} & $\begin{array}{l}\text { latent } \\
\text { crisis }\end{array}$ & [y1,y2] & {$[1,2]$} \\
\hline $\mathrm{h}$ & crisis & $\geq_{x 3}$ & 3 & $\begin{array}{l}\text { latent } \\
\text { crisis }\end{array}$ & {$[\mathrm{y} 1, \mathrm{y} 2]$} & {$[1,2]$} \\
\hline $\mathrm{i}$ & non- & {$[0, \mathrm{x} 1]$} & {$[0,1]$} & devel & {$[\mathrm{y} 2, \mathrm{y} 3]$} & {$[2,3]$} \\
\hline
\end{tabular}

\begin{tabular}{|c|c|c|c|c|c|c|}
\hline & crisis & & & $\begin{array}{l}\text { oping } \\
\text { crisis }\end{array}$ & & \\
\hline $\mathrm{j}$ & $\begin{array}{l}\text { latent } \\
\text { crisis }\end{array}$ & {$[\mathrm{x} 1, \mathrm{x} 2]$} & {$[1,2]$} & $\begin{array}{l}\text { devel } \\
\text { oping } \\
\text { crisis }\end{array}$ & {$[\mathrm{y} 2, \mathrm{y} 3]$} & {$[2,3]$} \\
\hline $\mathrm{k}$ & $\begin{array}{c}\text { develo } \\
\text { ping } \\
\text { crisis }\end{array}$ & {$[\mathrm{x} 2, \mathrm{x} 3]$} & {$[2,3]$} & $\begin{array}{l}\text { devel } \\
\text { oping } \\
\text { crisis }\end{array}$ & {$[\mathrm{y} 2, \mathrm{y} 3]$} & {$[2,3]$} \\
\hline 1 & crisis & $\geq_{x 3}$ & 3 & $\begin{array}{l}\text { devel } \\
\text { oping } \\
\text { crisis }\end{array}$ & {$[\mathrm{y} 2, \mathrm{y} 3]$} & {$[2,3]$} \\
\hline $\mathrm{m}$ & $\begin{array}{l}\text { non- } \\
\text { crisis }\end{array}$ & {$[0, \mathrm{x} 1]$} & {$[0,1]$} & crisis & $\geq_{\mathrm{y} 3}$ & 3 \\
\hline $\mathrm{n}$ & $\begin{array}{l}\text { latent } \\
\text { crisis }\end{array}$ & {$[\mathrm{x} 1, \mathrm{x} 2]$} & {$[1,2]$} & crisis & $z_{y 3}$ & 3 \\
\hline o & $\begin{array}{l}\text { devel } \\
\text { oping } \\
\text { crisis }\end{array}$ & {$[\mathrm{x} 2, \mathrm{x} 3]$} & $\begin{array}{c}{[2,3} \\
]\end{array}$ & $\begin{array}{c}\text { crisi } \\
\mathrm{S}\end{array}$ & $\geq \mathrm{y} 3$ & 3 \\
\hline $\mathrm{p}$ & crisis & $\geq \mathrm{x} 3$ & 3 & $\begin{array}{c}\text { crisi } \\
\mathrm{S}\end{array}$ & $\geq \mathrm{y} 3$ & 3 \\
\hline
\end{tabular}

For the reason of the accumulation and expansion characteristic of financial risk, we use R-value to measure the risk level, and a different R-value corresponds to a different risk areas. The general interpretation of matrix region can be also given. For example, if the matrix region is " $\mathrm{A}$ ", the economic meaning of it can be explains as: both $\mathrm{X}$ and $\mathrm{Y}$ have "none-crisis" risk levels. This paper designs an index system including FER index $t_{i 1}, \mathrm{MCR}$ index $t_{i 2}$, EFR index $t_{i 3}$, OPR index $t_{i 4}$, INR index $t_{i 5}$, FIR index $t_{i 6}$, FCR index $t_{i 7}$, CCR index $t_{i 8}$, OCR index $t_{i 9}$, LPR index $t_{i 10}$

Enterprise's financial risks can be identified through matrixes, including FEAR identification matrix, FRAR identification matrix and FSCR identification matrix.

FEAR identification matrix uses FER R-value ( $\left.x_{i 1}\right)$ as lateral axis, and market and element integrated risk $\mathrm{R}$ value $\left(y_{i 1}\right)$ as longitudinal axis. And in constructing FRAR identification matrix, FCR R-value $\left({ }^{x_{i 2}}\right)$ is lateral axis, and comprehensive risk R-value of operation, investment \& financing ( $\left.y_{i 2}\right)$ is longitudinal axis. And in FSCR identification matrix, this paper adopts LPR R-value $\left(x_{i 3}\right)$ as lateral axis, and stakeholder cooperation risk Rvalue $\left(y_{i 3}\right)$ as longitudinal axis (the formulas are $7,8,9$ ). The judgments of three-dimensional financial risks identification matrix are mainly based on the regions where the value is in.

\section{ALGORITHM}

Suppose the sample number of enterprise is $\mathrm{n}$ in an industry what means the domain is $U=\left\{u_{1}, u_{2}, \mathrm{~K}, u_{n}\right\}$ And if the financial risks index vector set is $\mathrm{T}=\left\{t_{i 1}, t_{i 2}, \mathrm{~K}, t_{i m}\right\}$, risk controlling point vector set is 
$\eta=\left\{\eta_{1}, \eta_{2}, \mathrm{~K}, \eta_{m}\right\}$, then the calculated risk index can be get from the follow formula:

$$
z_{i j}=\left|1-t_{i j} / \eta_{j}\right|
$$

Where $z_{i j}$ is the calculated $\mathrm{j}$-th value of i-th enterprise, ${ }^{\eta_{j}}$ and $t_{i j}$ separately represent risk controlling point indexvalue and actual risk index value $(i=1,2, \mathrm{~L}, n ; j=1,2, \mathrm{~L}, m)$

Risk controlling point value $\eta_{j}$ can be calculated byformula 2 , actual value $t_{i j}$ an be calculated from theformulas of the built indexes (not given in this paper), $\mathrm{R}$-values can be calculated by formula 1 . So the calculated risklevel vector set can be expressed as $\mathrm{R}_{i}=\left\{R_{i 1}, R_{i 2}, \mathrm{~K}, R_{i m}\right\}$

The FEAR R-value, the FRAR R-value and the FSCR Rvalue can be calculated through the following formulas:

$$
\begin{gathered}
R_{-} F R A R_{i}=\sum_{j=1}^{3} \omega_{j}^{1} \mathrm{~g} R_{i j} \\
R_{-} F R A R_{i}=\sum_{j=4}^{7} \omega_{j}^{2} \mathrm{~g} R_{i j} \\
R_{-} F R A R_{i}=\sum_{j=8}^{10} \omega_{j}^{3} \mathrm{~g} R_{i j}
\end{gathered}
$$

Where

$$
\omega_{j}^{1}=\frac{R_{j}}{\sum_{j=1}^{3} R_{j}} \quad \sum_{j=1}^{3} \omega_{j}^{1}=1 \quad \omega_{j}^{2}=\frac{R_{j}}{\sum_{j=4}^{7} R_{j}}
$$

$$
\sum_{j=4}^{7} \omega_{j}^{2}=1 \quad \omega_{j}^{3}=\frac{R_{j}}{\sum_{j=8}^{10} R_{j}} \sum_{j=8}^{10} \omega_{j}^{3}=1
$$

Calculation of FEAR identification matrix adopts following formula:

$$
\left\{\begin{array}{l}
x_{i 1}=R_{i 3} \\
y_{i 1}=\sqrt{R_{i 1} g R_{i 2}}
\end{array}\right.
$$

Calculation of FRAR identification matrix adopts following formula:

$$
\left\{\begin{array}{l}
x_{i 2}=R_{i 7} \\
y_{i 2}=\sqrt[3]{R_{i 4} \mathrm{~g} R_{i 5} \mathrm{~g} R_{i 6}}
\end{array}\right.
$$

And calculation of FSCR identification matrix adopts following formula:

$$
\left\{\begin{array}{l}
x_{i 3}=R_{i 10} \\
y_{i 3}=\sqrt{R_{i 8} \mathrm{~g} R_{i 9}}
\end{array}\right.
$$

\section{CONCLUSION}

This paper gives some theoretical analysis and builds a matrix model for three-dimensional financial risks' identification. The main contributions can be summarized as follows:

(1)Connotation of financial risks has broken through traditional risk view, and has obvious features of dimension. Based on the understanding of enterprise's external environment, internal resources and stakeholders, three-dimensional financial risk is refers to financial environment-adaptation risk (FEAR), financial resourceallocation risk (FRAR) and financial stakeholdercooperation risk (FSCR).

(2)Three-dimensional financial risks are formed through the process of environmental adaptation, resource allocation and profits cooperation, and conduct by time and space paths. From time level, three-dimensional financial risks are conducted and spread following the path of "'non-risk period' to 'latent period' to 'development period' and to 'realization period"'. Analyzed from space level, three-dimensional financial risks are conducted and spread with the cycling path of "FEAR to FRAR and to FSCR".

(3)It explores the identifying principle of threedimensional financial risks, builds financial risk identification matrixes including FEAR identification matrix, FRAR identification matrix and FSCR identification matrix

\section{REFERENCES}

[1] J. Argenti, “Corporate collapse: the causes and symptoms,"London: McGraw-Hill, 1976.

[2] D. Ginoglou, K. Agorastos and T. Hayzigagios, "Predicting corporate failure of problematic firms in Greece with LPM, logit, probit and discriminant analysis models," Journal of Finance Management and Analysis, 2010, 15(1), pp.1-15.

[3] S. Peng, J. Xing, “Corporate financial crisis,"BeiJing: Tsinghua University Press, 2009.

[4] M. E. Porter, "The competitive advantage of nations," New York: The Free Press, 1990.

[5] Y. Zhang, Z. Feng and S. Jiang, "Research on 3D financial risks \& competitiveness of enterprise based on porter diamond model," Proceedings of the 5th International Conference on Innovation \& Management. Maastricht, the Netherlands, December 10-11, 2010, pp.1044-1048. 